\title{
Penelitian dan Pengembangan Sistem Mutu Akuntansi Keuangan Pada Usaha Ternak Ayam Potong Blitar
}

\author{
Defia Nurbatin ${ }^{1}$ \\ STIE Indocakti Malang \\ devia.nurbatin@gmail.com \\ Hendy Hermawan ${ }^{2}$ \\ STIE Indocakti Malang \\ Hendy.indocakti@yahoo.com
}

\begin{abstract}
The purpose of this research is to arrange guidance of recording to financial reporting as model of development of financial accounting quality system at Cak Wanto chicken farm in Blitar. The method used in this research is the research \& development model of DBR (Design Based Research) from Purwiyanto (2014) which is modified. Research phase starts from problem identification, data collection, product preparation, product test (expert validation) and final product refinement. Data collection techniques are Focus Group Discussion, observation, interview, and questionnaire (questionnaire). Questionnaire as an expert validation instrument consists of 4 aspects of the assessment of aspects of usability, convenience, completeness, and legibility. Techniques used to analyze data validation scoring results are to use a percentage technique with the category of interval Before-After technique. This study produces a quality system in the form of three SOPs that show the application of SOP can run effectively to be implemented with evidence of the average percentage results near perfect and in accordance with user needs.
\end{abstract}

Keywords: 1: Quality Accounting System 2: Standard Operating Procedures

\section{PENDAHULUAN}

Pembangunan peternakan pada era globalisasi bertujuan untuk mewujudkan masyarakat yang sehat, produktif dan kreatif melalui peternakan yang tangguh berbasis sumber daya lokal, sehingga produk ayam lokal bisa bersaing dengan adanya ayam impor yang sudah mulai membanjiri Indonesia. Selain itu, dilihat dari segi peluang pasar, pengembangan agribisnis peternakan memiliki prospek yang baik khususnya dalam memenuhi kebutuhan domestik yang semakin meningkat (Simatupang et al., 2004). Hal tersebut didukung dengan mulai berkembangnya kepemilikan peternakan ayam lokal khususnya di pedesaan, sehingga dapat mendorong timbulnya usaha baru sekaligus lapangan kerja bagi masyarakat.

Usaha bisnis ternak ayam yang saat ini telah sejak lama berkembang di Indonesia dan diminati oleh pelaku bisnis usaha kecil menengah yaitu peternakan ayam potong broiler yang ditumbuh kembangkan oleh peternak di pedesaan. Perkembangan usaha kepemilikan 
Defia Nurbatin dan Hendy Hermawan, Penelitian dan Pengembangan Sistem Mutu Akuntansi Keuangan Pada Usaha Ternak Ayam Potong Blitar . peternakan ayam lokal di pedesaan disebabkan peternakan ayam merupakan usaha yang dapat dibagi sesuai dengan status produksinya yaitu ayam potong lokal diawali dengan usaha memproduksi telur tetas, dilanjutkan dengan usaha menetaskan telur, dan terakhir usaha memproduksi ayam siap potong atau menyuplai daging ayam potong. Segmen-segmen usaha tersebut dapat di implementasikan di suatu wilayah atau kelompok tani ternak yang anggotanya dapat memilih usaha sesuai dengan keahliannya masing-masing. Oleh karena pangsa pasar ayam potong lokal masih terbuka, sehingga jumlah petani atau peternak yang terlibat dalam rangkaian usaha tersebut cenderung makin meningkat. Seperti jenis peternak di pedesaan yang terbagi atas peternak plasma yang menjual hasil ternak ayam potong (pedaging) ke pedagang di pasar tradisional, atau peternak yang menjual ke pemasok bibit ayam sebagai perusahaan inti yang berperan membeli ternak yang telah ditumbuhkembangkan peternak menjadi ayam potong (pedaging).

Peternakan yang merupakan bagian dari kegiatan pertanian luas bertujuan untuk menghasilkan keuntungan bagi petani atau peternak dalam proses tumbuhkembangkan bibit ayam menjadi ayam ternak siap dijual. Namun untuk mencapai keuntungan dalam hal ini pencapaian target laba, bagi usaha ternak ayam potong di lingkungan pedesaan berjenis usaha kecil mikro menengah ini belum memiliki sistem pembukuan terstruktur mulai dari pengelolaan keuangan sampai pelaporan keuangannya. Oleh karenanya sebagai upaya pencapaian target laba diperlukan pengembangan usaha dengan cara menyusun sistem mutu agar menunjang sistem pembukuan usaha tertata rapi dan memiliki estimasi laba sehingga menunjang seluruh kegiatan operasional usaha ternak ayam potong. Menurut Ekotama (2010: 19), sistem mutu adalah sistem yang digunakan untuk memudahkan, merapikan dan menertibkan pekerjaan. Sistem ini berisi urutan melakukan pekerjaan dari awal hingga akhir. Sistem mutu merupakan pedoman tertulis kegiatan (pekerjaan) yang dilakukan suatu usaha bisnis atau perusahaan. Oleh karena itu, jika di dalam suatu organisasi bisnis atau perusahaan tidak ada sistem mutu maka akan timbul masalah yang menghambat efsisiensi dan efektivitas serta menurunkan kinerja usaha tersebut.

Peneliti telah melakukan observasi dan wawancara sebelumnya dengan salah satu peternak di Desa Pohgajih Kecamatan Selorejo Kabupaten Blitar yang memiliki usaha ternak ayam potong broiler. Bapak Siswanto selaku pemilik ternak dan berperan sebagai peternak plasma yang menumbuh kembangkan bibit ayam broiler yang di beli dari pemasok (supplier) 
Defia Nurbatin dan Hendy Hermawan, Penelitian dan Pengembangan Sistem Mutu Akuntansi Keuangan Pada Usaha Ternak Ayam Potong Blitar . yang kemudian nantinya menjadi ternak ayam pedaging yang siap dijual kembali ke pemasok selaku perusahaan inti.

Peneliti mengajukan beberapa pertanyaan terutama terkait jumlah omset yang diperoleh dari usaha peternakan plasma tersebut di beberapa periode bejalan terakhir. Namun, peternak Siswanto atau "Cak Wanto" tidak mampu menyebutkan fluktuasi kestabilan naik turunnya omset yang diperoleh dan tidak tahu persis melakukan pencatatan sebagai kelola dana kas saat ketika mengalami omset bila hasil penjualan ternak laku dan rugi bila harus menanggung biaya operasional pakan ternak yang tinggi. Oleh karenanya, untuk mengatasi pembukuan dan kelola keuangan yang tidak ada di usaha ternak pak Siswanto tersebut sangat diperlukan suatu sistem mutu akuntansi sebagai pedoman (panduan) terstandar akuntansi keuangan agar dapat melakukan pembukuan tidak sesederhana kas masuk dan keluar, serta estimasi anggaran sebagai kelola hasil penjualan. Agar kegiatan pengelolaan dan pelaporan keuangan tersistem mutu sesuai Standar Akuntansi Keuangan diperlukan adanya sistem mutu yang terdiri dari visi, misi, struktur organisasi, kebijakan mutu, Standard Operational Prosedur dan Intruksi Kerja. Dalam penyusunan sistem mutu akuntansi keuangan di usaha ternak ayam potong Cak Wanto ini, peternak Siswanto telah menyerahkan sepenuhnya mengenai sistem mutu yang disusun dan dikembangkan peneliti sesuai kebutuhan di Peternakan ayam Cak Wanto tersebut.

Tujuan dari penelitian dan pengembangan ini adalah untuk menyusun panduan alur pencatatan hingga pelaporan keuangan sebagai model pengembangan sistem mutu akuntansi keuangan pada usaha ternak ayam potong Cak Wanto di Blitar. Spesifikasi produk yang diharapkan dari penelitian dan pengembangan ini berupa sistem mutu akuntansi yang terdiri yaitu Visi, Misi, Tujuan, Sturktur organisasi, Jabaran tugas, Kebijakan mutu dan Standar Operasional Prosedur. Namun karena di usaha ternak ayam Cak Wanto tersebut belum ada pembukuan yang tersistem akuntansi sedangkan pemilik ternak membutuhkan pembukuan sebagai informasi keuntungan dari usaha ternaknya, maka peneliti membatasi dalam penelitian dan pengembangan sistem mutu akuntansi keuangan ini hanya pada fokus penyusunan dan pengembangan sistem mutu berwujud Standar Operational Prosedur. Agar SOP lebih simpel dan mudah dipahami oleh pihak-pihak dalam usaha ternak dan tidak menghilangkan bagian sistem mutunya, maka SOP yang disusun mencantumkan sekaligus Visi, Misi, Tujuan, Struktur organisasi, Jabaran tugas dan Kebijakan mutu akuntansi keuangan. 
Defia Nurbatin dan Hendy Hermawan, Penelitian dan Pengembangan Sistem Mutu Akuntansi Keuangan Pada Usaha Ternak Ayam Potong Blitar .

Pentingnya penelitian dan pengembangan bagi peneliti yaitu dapat sebagai pemecahan masalah secara ilmiah dan mampu menghasilkan produk baru berupa sistem mutu melalui proses pengembangan. Sedangkan bagi peternak sekaligus pemilik usaha peternakan ayam potong di Blitar yaitu (1) dapat memecahkan masalah terutama kelola keuangannya dan meningkatkan kualitas ternak yang dijual sehingga target laba tercapai; (2) dapat memperoleh serta menerapkan sistem mutu dari peneliti dan mengembangkannya bila perlu; (3) menghemat waktu dan biaya untuk pembuatan sistem mutu.

Asumsi penelitian dan pengembangan ini yaitu (1) Dengan sistem mutu akuntansi keuangan, kegiatan pembukuan dalam usaha peternakan ayam potong Cak Wanto yang berbentuk kemitraan peternak plasma akan lebih efektif dan efisien; (2) Management by System lebih baik daripada management by people; (3) pemilik usaha ternak dapat mengembangkan kembali sistem mutu yang telah disusun peneliti. Sedangkan keterbatsan penelitian dan pengembangan yaitu (1) tidak dapat diujicobakan pada keseluruhan produk dikarenakan durasi waktu penelitian yang terbatas; (2) karyawan di dalam usaha ternak Cak Wanto jumlahnya terbatas karena masih berbentuk usaha kecil mikro menengah yang tidak lebih dari 10 orang sehingga beberapa prosedur tidak dapat diujicobakan kepada user atau peternak.

Definisi operasional dari penelitian terdiri dari (1) Penelitian dan Pengembangan adaah metode penelitian yang didalamnya terdapat proses atau langkah-langkah untuk menghasilkan produk baru, menyempurnakan atau mengembangkan produk yang sudah ada, kemudian memvalidasi dan menguji keefektifan produk tersebut agar dapat dipertanggungjawabkan; (2) Sistem Mutu Akuntansi Keuangan adalah sistem yang berisi pedoman atau acuan untuk memudahkan, merapikan dan menertibkan pencatatan sesuai alur siklus akuntansi (input, proses, output) yang menghasilkan informasi keuangan dalam bentuk output laporan keuangan, yang mana sistem mutu akuntansi tersebut meliputi visi, misi, tujuan, struktur oganisasi, jabaran tugas, kebijakan mutu hingga Standar Operasional Prosedur.

\section{TELAAH TEORITIS}

\section{Penelitian dan Pengembangan}

Sugiyono (2011: 407) menyatakan bahwa metode penelitian dan pengembangan atau Research and Development adalah metode penelitian yang digunakan untuk menghasilkan 
Defia Nurbatin dan Hendy Hermawan, Penelitian dan Pengembangan Sistem Mutu Akuntansi Keuangan Pada Usaha Ternak Ayam Potong Blitar . produk tertentu dan menguji keefektifan produk tersebut. Sedangkan menurut Sujadi (2003: 164) Research and Development (R\&D) adalah suatu proses atau langkah-langkah untuk mengembangkan suatu produk baru, atau menyempurnakan produk yang telah ada, yang dapat dipertanggungjawabkan.

Penelitian dan pengembangan jika ditinjau dari segi proses adalah suatu jembatan yang menghubungkan antara penelitian dasar dengan penelitian terapan. Suriasumantri (2010) dalam Sugiyono (2011: 9) menyatakan bahwa penelitian dasar atau murni adalah penelitian yang bertujuan menemukan pengetahuan baru yang sebelumnya belum pernah diketahui, sedangkan penelitian terapan adalah bertujuan untuk memecahkan masalah kehidupan praktis. Ilustrasi di atas dapat dilihat pada Gambar 1.

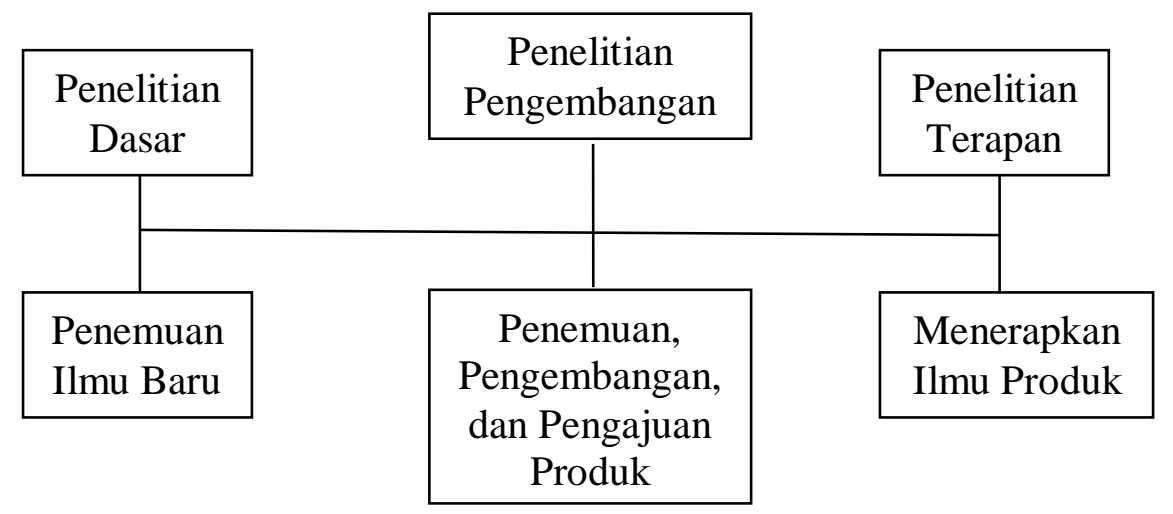

\section{Gambar 1. Kedudukan Penelitian dan Pengembangan Sebagai Jembatan}

Menurut Setyosari (2010), alasan dilakukannya penelitian dan pengembangan adalah karena pendekatan penelitian tradisional misalnya, penelitian survei, korelasi, eksperimen dengan fokus penelitian hanya mendeskripsikan pengetahuan, jarang memberikan deskripsi yang berguna dalam pemecahan masalah-masalah rancangan dan desain dalam pembelajaran. Sedangkan tujuan dari penelitian pengembangan menurut Mulyatiningsih (2011: 161) adalah menilai perubahan-perubahan yang terjadi selama kurun waktu tertentu dan menghasilkan produk baru melalui proses pengembangan.

Berdasarkan pendapat para ahli di atas, dapat ditarik kesimpulan bahwa penelitian dan pengembangan adalah metode penelitian yang di dalamnya terdapat proses atau langkahlangkah untuk menghasilkan produk baru, menyempurnakan atau mengembangkan produk yang sudah ada, kemudian memvalidasi dan menguji keefektifan produk tersebut agar dapat dipertanggungjawabkan. 
Defia Nurbatin dan Hendy Hermawan, Penelitian dan Pengembangan Sistem Mutu Akuntansi Keuangan Pada Usaha Ternak Ayam Potong Blitar .

\section{Model Penelitian dan Pengembangan}

a. Model Penelitian Pengembangan Hannafin dan Peck. Hannafin dan Peck (1988) mengemukakan model penelitian dan pengembangan dengan desain pengajaran yang terdiri dari tiga fase yaitu fase analisis keperluan, fase desain, dan fase pengembangan dan implementasi. Model Hannafin dan Peck merupakan salah satu dari banyak model desain pembelajaran yang berorietasi produk. Model berorientasi produk adalah model desain pembelajaran utuk menghasilkan suatu produk.

b. Model Penelitian Pengembangan Borg and Gall. Borg and Gall (1983) menyatakan bahwa prosedur penelitian pengembangan pada dasarnya terdiri dari dua tujuan utama, yaitu mengembangkan produk dan menguji keefektifan produk dalam mencapai tujuan. Borg and Gall (1983) memaparkan sepuluh langkah pelaksanaan model penelitian dan pengembangan yaitu: (1) Penelitian dan pengumpulan data (research and information collecting); (2) Perencanaan (planning); (3) Pengembangan draf produk (develop preliminary form of product); (4) Uji coba lapangan awal (preliminary field testing); (5) Merevisi hasil uji coba (main product revision); (6) Uji coba lapangan (main field testing); (7) Penyempurnaan produk hasil uji lapangan (operasional product revision); (8) Uji pelaksanaan lapangan (operasional field testing); (9) Penyempurnaan produk akhir (final product revision); (10) Diseminasi dan implementasi (dissemination and implementation)

c. Design Based Research (DBR). Penelitian berbasis desain memiliki peran dalam perkembangan kapasitas manusia untuk reformasi pendidikan selanjutnya. Menurut Purwiyanto (2014) penelitian berbasis desain dapat membantu menciptakan dan memperluas pengetahuan untuk mengembangkan, melaksanakan, dan melanjutkan lingkungan belajar inovatif. Menurut Purwiyanto (2014) langkah pengembangan pendekatan Design Based Research (DBR) meliputi 6 (enam) langkah yaitu Identifikasi masalah, identifikasi tujuan, penyusunan desain dan pengembangan struktur isi, uji desain dan struktur isi, evaluasi hasil uji desain dan struktur isi, serta komunikasi hasil uji desain dan struktur isi.

Untuk penelitian dan pengembangan kali ini, peneliti menggunakan Design Based Research (DBR) sebagai model penelitian dan pengembangan. Peneliti menggunakan model penelitian dan pengembangan DBR dikarenakan beberapa alasan, yaitu karakteristik DBR 
Defia Nurbatin dan Hendy Hermawan, Penelitian dan Pengembangan Sistem Mutu Akuntansi Keuangan Pada Usaha Ternak Ayam Potong Blitar .

salah satunya adalah utility oriented yang berarti produk bisa digunakan secara praktis sesuai kebutuhan pengguna. Dibandingkan model penelitian dan pengembangan lain, model penelitian dan pengembangan DBR lebih cocok digunakan karena produk yang dihasilkan adalah customize atau tidak massal. Dalam langkah-langkah penelitian, DBR selalu melibatkan praktisi sebagai partisipan dan bekerja sama secara kolaboratif dengan peneliti untuk mendapatkan masukan dalam setiap prosesnya, sehingga produk yang dihasilkan akan lebih sesuai jika nanti diterapkan.

\section{Sistem Mutu}

Sistem secara umum merupakan sekelompok unsur yang erat hubungannya satu dengan yang lain yang berfungsi bersama-sama untuk mencapai tujuan tertentu. Sebuah sistem memiliki karakteristik atau sifat-sifat tertentu. Karakteristik sistem yaitu sebagai komponen sistem (components), sebagai batasan sistem (boundary), sebagai lingkungan luar sistem (environment), sebagai penghubung sistem (interface) yang menghubungkan sistem dengan subsistem lain, sebagai masukan sistem (input), sebagai keluaran sistem (output), sebagai pengolahan sistem (proses), dan sebagai sasaran sistem (objective) (Mulyadi, 2016:2).

Sistem mutu menurut Nurbatin (2016) merupakan konsep dan teori dari pengelolaan kegiatan yang telah dikembangkan sejak awal dan mendorong dikembangkannya konsep mutu pengelolaan keuangan dan jasa pelayanan yang menghasilkan suatu instrumen pengelolaan bisnis manajemen, oleh karena itu Standar Operasional Prosedur berlandaskan pada sistem manajemen kualitas (Quality Management System). Manajemen kualitas adalah sekumpulan prosedur yang terdokumentasi dan praktek-praktek standar untuk manajemen sistem yang bertujuan menjamin kesesuaian dari suatu proses dan produk (barang dan/atau jasa) terhadap kebutuhan atau persyaratan tertentu. Menurut Atmoko (2012: 11) sistem mutu merupakan suatu pedoman atau acuan untuk melaksanakan tugas pekerjaan sesuai dengan fungsi dan alat penilaian kinerja instansi pemerintah berdasarkan indikator-indikator teknis, administratif dan prosedural sesuai tata kerja, prosedur kerja, dan sistem kerja pada unit kerja yang bersangkutan.

Berdasarkan pendapat peneliti dan ahli di atas, dapat ditarik kesimpulan bahwa sistem mutu adalah suatu sistem yang berisi pedoman atau acuan untuk memudahkan, merapikan dan menertibkan pelaksanaan pekerjaan.

Jurnal Akuntansi dan Teknologi informasi (JATI) Vol. 12 No.1 Tahun 2018 
Defia Nurbatin dan Hendy Hermawan, Penelitian dan Pengembangan Sistem Mutu Akuntansi Keuangan Pada Usaha Ternak Ayam Potong Blitar .

\section{Bagian Sistem Mutu}

Produk yang diharapkan dari penelitain dan pengembangan ini berupa sistem mutu yang terdiri dari beberapa bagian, yaitu:

1. Visi merupakan serangkaian kata-kata bahkan rangkaian kalimat mengungkapkan impian, cita-cita, rencana, harapan sebuah perkumpulan, perusahaan, organisasi yang ing in dicapai di masa mendatang (Wibisono, 2006: 43).

2. Wibisono (2006: 46-47) menyatakan Misi adalah untaian kalimat yang berisi tujuan dan alasan keberadaan suatu organisasi yang memuat apa yang disediakan oleh perusahaan atau organisasi kepada masyarakat, berupa produk dan jasa.

3. Menurut Robbins dan Coulter (2010: 284) struktur organisasi dapat diartikan sebagai kerangka kerja formal organisasi yang dengan kerangka kerja itu tugas-tugas pekerjaan dibagi-bagi, dikelompokkan, dan dikoordinasikan.

4. Kebijakan mutu adalah sebuah statement komitmen yang disampaikan institusi. Jika sebuah institusi menggunakan sebuah standar, maka standar tersebut harus benar-benar diikuti. Dengan demikian kebijakan mutu merupakan kebijakan resmi dan tertulis dari pimpinan puncak perusahaan tentang komitmen perusahaan dalam memperhatikan dan mempertimbangkan aspek-aspek mutu dalam aktifitas keseharian organisasi atau perusahaan.

5. SOP atau Standar Operasional Prosedur adalah dokumen yang berisi serangkaian instruksi tertulis yang dibakukan mengenai berbagai proses penyelenggaraan administrasi perkantoran atau usaha yang berisi cara melakukan pekerjaan, waktu pelaksanaan, tempat penyelenggaraan, dan pihak yang berperan dalam kegiatan (Insani, 2010: 1).

\section{Akuntansi Keuangan}

Akuntansi adalah aktivitas mengumpulkan, menganalisis, menyajikan dalam bentuk angka, mengklasifikasikan, mencatat, meringkas, dan melaporkan aktivitas/transaksi suatu usaha dalam bentuk informasi keuangan. (Rudianto, 2012: 4). Proses akuntansi itu sendiri meliputi suatu siklus akuntansi yang tersturktur. Menurut Purwiyanto (2015: 13-14), siklus akuntansi merupakan suatu proses akuntansi yang terus berputar, mulai dari pencatatan transaksi keuangan di jurnal sampai dengan penyusunan laporan keuangan (laporan laba rugi, 
Defia Nurbatin dan Hendy Hermawan, Penelitian dan Pengembangan Sistem Mutu Akuntansi Keuangan Pada Usaha Ternak Ayam Potong Blitar . laporan perubahan modal, dan neraca). Secara prosedural proses akuntansi meliputi tahaptahap yaitu pencatatan bukti-bukti transaksi ke jurnal, mem-posting ke buku besar, dan menyusun laporan keuangan. Output yang berupa informasi yang tersaji didalam laporan keuangan akan berguna untuk pengambil keputusan bagi pihak internal perusahaan maupun eksternal perusahaan.

Menurut Martani (2012: 8), akuntansi keuangan berorientasi pada pelaporan pihak eksternal. Beragamnya pihak eksternal dengan tujuan spesifik bagi masing-masing pihak membuat pihak penyusun laporan keuangan menggunakan prinsip dan asumsi-asumsi dalam penyusunan laporan keuangan. Untuk itu diperlukan standar akuntansi yang dijadikan pedoman baik oleh penyusun maupun oleh pembaca laporan keuangan. Laporan yang dihasilkan dari akuntansi keuangan berupa laporan keuangan untuk tujuan umum (general purpose financial statement).

Berdasarkan pemahaman akuntansi keuangan yang diungkapkan para ahli tersebut, dapat disimpulkan bahwa akuntansi keuangan adalah proses mengumpulkan, mencatat, dan mengkomunikasikan informasi ekonomi berupa transaksi dan kejadian yang bersifat keuangan dan penginterpretasian hasil proses tersebut sehingga memungkinkan adanya pelaksanaan dan penilaian jalannya perusahaan secara efisien, serta memperoleh pertimbangan dan keputusan yang tepat oleh pemakai informasi yang bersangkutan.

\section{Sistem Mutu Akuntansi Keuangan}

Sistem mutu adalah suatu sistem yang berisi pedoman atau acuan untuk memudahkan, merapikan dan menertibkan pelaksanaan pekerjaan meliputi visi, misi, tujuan, struktur organisasi, jabaran tugas, kebijakan mutu, Standar Operasional Prosedur (SOP), dan Instruksi Kerja (IK). Sedangkan akuntansi keuangan adalah proses mengumpulkan, mencatat, dan mengkomunikasikan informasi ekonomi berupa transaksi dan kejadian yang bersifat keuangan dan penginterpretasian hasil proses tersebut dalam bentuk laporan keuangan sehingga memperoleh pertimbangan dan keputusan yang tepat oleh pemakai informasi yang bersangkutan.

Berdasarkan kajian pustaka yang telah dipaparkan, sistem mutu akuntansi keuangan menurut peneliti adalah suatu sistem yang berisi pedoman atau acuan untuk memudahkan, merapikan dan menertibkan pencatatan yang menghasilkan informasi keuangan dalam bentuk 
Defia Nurbatin dan Hendy Hermawan, Penelitian dan Pengembangan Sistem Mutu Akuntansi Keuangan Pada Usaha Ternak Ayam Potong Blitar . laporan keuangan di mana sistem mutu akuntansi keuangan tersebut meliputi visi, misi, tujuan, struktur organisasi, jabaran tugas, kebijakan mutu dan SOP.

Agar mencapai keefektifan penerapan sistem mutu akuntansi keuangan di usaha ternak ayam potong Cak Wanto dan sesuai kebutuhan user (pemilik ternak) peneliti membatasi lingkup hanya pada penyusunan dan pengembangan sistem mutu berwujud Standar Operational Prosedur. Namun demikian, didalam SOP tetap menjabarkan beberapa bagian sistem mutu seperti Visi, Misi, Tujuan dari Peternakan "Cak Wanto” disesuiakan dengan lingkup usahanya yang berbentuk usaha mikro kecil menengah.

\section{METODE PENELITIAN}

\section{Model Penelitian dan Pengembangan}

Peneliti menggunakan model penelitian pengembangan karena peneliti membuat kerangka berfikir yang didasarkan pada analisis kebutuhan yang kemudian dituangkan dalam bentuk Standard Operating Procedure (SOP). Langkah-langkah pengembangan yang dilakukan oleh peneliti mengikuti pendekatan model Purwiyanto (2014) yaitu Design Based Research (DBR). Tahapan pendekatan DBR yaitu (1) Identifikasi Masalah; (2) Identifikasi kebutuhan, (3) Penyusunan desain dan struktur isi bahan pelatihan; (4) Uji Coba; (5) Evaluasi hasil uji coba; (6) Komunikasi dengan user dan validator ahli hasil evaluasi dengan revisi akhir. Berdasarkan langkah-langkah tersebut, peneliti melakukan modifikasi yang disesuaikan dengan tujuan dan kebutuhan penelitian dengan tahapan pendekatan yaitu (1) Identifikasi masalah dan kebutuhan; (2) Pengumpulan data dan Informasi; (3) Perencanaan dan penyusunan SOP;(4) Uji Coba Produk atau validasi oleh ahli (akademisi dan praktisi); (5)

Penyempurnaan produk akhir

Alasan pemilihan pendekatan DBR, sebagai acuan untuk membuat modifikasi prosedur penelitian pengembangan, adalah (1) Langkah-langkah penelitian pengembangannya adalah sederhana, mudah diaplikasikan dan bersifat customize yang merupakan bukan produk massal; (2) Proses pengumpulan data yang dilakukan selalu melibatkan user sehingga dapat membantu peneliti untuk membuat SOP sesuai kebutuhan peternakan; (3) Urutan tiap tahapan tersusun secara sistematis sehingga pelaksanaan lebih terkontrol dengan baik; (4) penghematan waktu, biaya, dan tenaga sehingga menguntungkan bagi peneliti dalam melakukan uji coba produk atau tahap validasi produk; (5) uji coba pemakaian dan revisi produk berikutnya tidak digunakan, karena setelah dilakukan revisi produk dari pihak ahli 
Defia Nurbatin dan Hendy Hermawan, Penelitian dan Pengembangan Sistem Mutu Akuntansi Keuangan Pada Usaha Ternak Ayam Potong Blitar . akademisi dan praktisi langsung dilakukan penyempurnaan produk akhir atau dicetak berupa buku sistem mutu berwujud SOP akuntansi keuangan.

\section{Prosedur Penelitian Pengembangan}

Penelitian pengembangan dilakukan dalam lima tahapan prosedur, yaitu:

1. Identifikasi Masalah dan Kebutuhan. merupakan tahap awal dari pengembangan sistem mutu bidang Akuntansi dan Keuangan melalui observasi dan wawancara. Dari hasil observasi dan wawancara dengan pemilik, diperoleh informasi bahwa peternakan ayam potong "Cak Wanto" belum memiliki sistem mutu terkait pencatatan laporan keuangan dan pengelolaan keuangan untuk usaha bisnis ternak. Sistem yang ada adalah tidak tertulis sehingga peternak mengalami kesulitan dalam hal pembukuan keuangan sehingga pencapaian laba tidak maksimal dari hasil ternak daging ayam. Oleh karenanya dilakukan revisi produk terhadap prosedur yang telah ada sebelumnya di peternakan Blitar. Untuk tujuan di tahap ini dilakukan tehnik Focus Group Discussion yang melibatkan Tim peneliti, Dosen bidang Akuntansi dan Keuangan dan Pemilik Peternakan.

2. Pengumpulan Data. Data yang dikumpulkan merupakan bahan dalam pengembangan produk sistem mutu yang berwujud SOP. Tujuannya agar peneliti dapat menentukan beberapa aspek dalam SOP yang kemudian dikembangkan menjadi produk akhir yang dapat mengatasi permasalahan dalam prosedur usaha antara peternak plasma (peternak pak Siswanto) dengan perusahaan inti (supplier sarana produksi ternak yaitu PT. Sinar Sentosa Malang) agar sama-sama saling menguntungkan dalam transaksi jual-beli bibit ayam dan tumbuh kembang ayam pedaging. Data dikumpulkan dengan cara yaitu wawancara, observasi, dokumentasi dan kuesioner (angket) yang dilakukan untuk menguji tingkat validitas (uji coba) dari sistem mutu yang berwujud SOP.

3. Perencanaan dan Penyusunan SOP. Bertujuan untuk mendesain dan mengembangkan SOP sebagai hasil akhir penelitian;

4. Uji Produk/Validasi Ahli. Kegiatan ini bertujuan untuk mengetahui apakah SOP yang telah dibuat layak pakai. Validator terdiri dari satu akademisi (Dosen Ekonomi STIE Indocakti) dan satu praktisi lapangan dari peternakan. Dosen validator merupakan dosen jurusan ekonomi yang memiliki keahlian dan pengalaman dalam penulisan SOP, khususnya bidang akuntansi dan keuangan. Praktisi yang menjadi validator adalah salah satu dari beberapa peternak ayam di wilayah Blitar yang juga satu-satunya pemilik 
Defia Nurbatin dan Hendy Hermawan, Penelitian dan Pengembangan Sistem Mutu Akuntansi Keuangan Pada Usaha Ternak Ayam Potong Blitar . peternakan ayam potong "Cak Wanto" yang memakai pola kemitraan, yaitu kerjasama peternak plasma sebagai pemeliharaan bibit ayam hingga panen dengan perusahaan inti sebagai supplier sarana produksi ternak. Dipilihnya praktisi ini, selain sebagai peternak ayam yang menjalankan usaha peternakan di Blitar juga mengetahui informasi alur transaksi jual beli pola kemitraan peternak plasma pada umumnya. Berikut adalah identitas dari validator untuk penelitian ini:

Tabel 1. Identitas Validator Ahli

\begin{tabular}{cl}
\hline No & \multicolumn{1}{c}{ Nama Validator } \\
\hline 1. & $\begin{array}{l}\text { Mohammad Rofiudin, SE.,M.Si (Dosen STIE Indocakti } \\
\text { Malang) }\end{array}$ \\
2. & Siswanto (Peternak Plasma di Blitar) \\
\hline
\end{tabular}

5. Penyempurnaan Produk Akhir. Kegiatan ini merupakan hasil yang diperoleh dari uji lapangan dengan membandingkan pengelolaan keuangan dan sistem akuntansi antara sesudah dengan sebelum adanya pedoman (SOP) dengan teknik before-after (Purwiyanto, 2014) dengan pola $\mathrm{O}_{1}><\mathrm{O}_{2} . \mathrm{O}_{1}$ adalah skor angket tingkat pengelolaan keuangan dan sistem akuntansi sebelum adanya pedoman (SOP). $\mathrm{O}_{2}$ adalah skor angket akuntansi keuangan dan kelola keuangan setelah adanya pedoman (SOP). Efektivitas model sistem akuntansi diukur dengan membandingkan skor $\mathrm{O}_{1}$ dengan $\mathrm{O}_{2}$. Jika skor $\mathrm{O}_{2}$ lebih besar daripada $\mathrm{O}_{1}$, maka model SOP dikatakan efektif. Produk ini adalah akhir dari revisi yang sesuai dengan saran dari validator, sehingga produk telah memiliki relevansi dan kesesuaian antara isi SOP yang diciptakan dengan SOP yang dikembangkan sehingga dapat bermanfaat bagi usaha peternakan ayam potong.

\section{Validasi Produk (Uji Coba Produk)}

Validasi produk merupakan kegiatan untuk menilai dan menguji apakah rancangan produk, dalam hal ini sistem kerja baru secara rasional akan lebih efektif dari yang lama atau tidak (Sugiono, 2011:302). Uji coba produk ini dilakukan untuk mengetahui apakah produk yang telah dirancang dalam penelitian ini yaitu produk SOP layak digunakan atau tidak. Uji coba produk ini juga dilakukan untuk mengetahui sejauh mana produk ini dapat mencapai tujuan bagi objek yang diteliti. Validasi atau Uji coba produk dalam penelitian ini meliputi tahap-tahap sebagai berikut: 
Defia Nurbatin dan Hendy Hermawan, Penelitian dan Pengembangan Sistem Mutu Akuntansi Keuangan Pada Usaha Ternak Ayam Potong Blitar .

1. Desain Validasi. Tahap uji coba produk pengembangan ini merupakan tahap dilaksanakannya evaluasi formatif yang terdiri atas uji validasi ahli. Tujuan dilakukannya tahap ini adalah untuk mengetahui tingkat kegunaan, kemudahan penggunaan, dan kelengkapan produk yang sedang dikembangkan sebelum produk digunakan. Hasil akhir dari kegiatan ini berupa desain produk lengkap dengan spesifikasinya yang kemudian siap untuk diujicoba. Desain produk yang disusun berupa sistem mutu dalam bentuk SOP.

2. Subjek Validasi. Subjek uji coba yang terkait dengan pengembangan produk sistem mutu bidang akuntansi dan keuangan agribisnis peternakan terdiri dari Pihak Akademisi dan Praktisi.

3. Jenis Data yang diperoleh merupakan data primer dan data sekunder. Data Primer diperoleh melalui wawancara kepada peternak plasma beserta pihak terkait usaha peternakan di Blitar. Sedangkan data sekunder diambil berupa data informasi alur transaksi jual beli sebelum dan sesudah masa panen ayam.

4. Instrumen Pengumpulan Data yang akan digunakan dalam penelitian dan pengembangan untuk menghasilkan produk sebagaimana tujuan dilakukan penelitian ini, yaitu:

a. Focus Group Discussion dengan Tim peneliti, Dosen bidang Keuangan dan Pemilik/peternak plasma untuk mengidentifikasi masalah dan kebutuhan terkait dengan alur transaksi hingga pelaporan keuangan yang terstandar sistem mutu akuntansi keuangan pada usaha peternakan ayam potong Cak Wanto di Blitar sebagai upaya meningkatkan laba hasil ternak. Berdasarkan hal tersebut dapat digunakan sebagai acuan dalam menyusun SOP.

b. Lembar observasi sebagai rubrik penilaian yang digunakan peneliti untuk pengamatan dan pencatatan secara langsung serta sistematik terhadap sistem dan prosedur agribisnis pola kemitraan peternakan ayam potong di Blitar.

c. Wawancara dengan peternak plasma yang sekaligus sebagai pemilik agribisnis peternakan.

d. Kuesioner untuk mendapatkan validasi. Ini merupakan teknik pengumpulan data yang dilakukan dengan cara memberi seperangkat pertanyaan/pernyataan tertulis. Pernyataan tertulis digunakan untuk memperoleh informasi dari 2 orang nara sumber yaitu seorang ahli di bidang akademisi ekonomi dan seorang ahli praktisi lapangan yaitu peternak plasma sebagai pemilik peternakan. Lembar validasi akan dianalisis untuk menentukan kelayakan sistem sekaligus sebagai panduan dalam revisi produk. 
Defia Nurbatin dan Hendy Hermawan, Penelitian dan Pengembangan Sistem Mutu Akuntansi Keuangan Pada Usaha Ternak Ayam Potong Blitar . Lembar validasi digunakan untuk mengumpulkan data sebagai aspek penilaian terkait manfaat SOP, kemudahan penggunaan SOP, kelengkapan SOP, dan keterbacaan SOP. Adapun lembar validasi ahli terdiri dari 2 lembar validasi penilaian atau tanggapan masing-masing untuk pihak akademisi dan pihak praktisi. Instrumen validasi ahli yang digunakan adalah perpaduan angket tertutup dan terbuka. Angket tertutup adalah angket yang sudah disediakan jawabannya sehingga responden tinggal memilih. Bentuk angket penilaian menggunakan format rating scale terhadap produk yang dikembangkan. Isi angket tersebut berupa pernyataan judul-judul SOP yang terkait dengan pengelolaan keuangan dan operasional pelayanan. Rating scale menggunakan skala Likert dengan 5 kategori skor. Tiap skor memiliki bobot yaitu skor $1=$ Sangat Rendah; skor 2= Rendah; skor 3= Cukup; skor 4= Tinggi; dan skor 5= Sangat Tinggi. Angket tertutup digunakan untuk memudahkan pengisian jawaban yang praktis dan cepat bagi responden dan memudahkan bagi peneliti untuk menganalisis data kuantitaif. Angket terbuka digunakan untuk memberikan data kualitatif berupa revisi, saran, dan komentar dari responden terkait sistem mutu bidang akuntansi dan keuangan.

5. Tehnik Analisis Data. Mengukur respon pengguna dan tim ahli terkait dengan kelayakan desain produk. Pengujian dilakukan dengan teknik prosentase mengikuti model Purwiyanto (2014) dan Sudarwati (2012) dengan formula:

$$
\frac{\text { Jumlah skor jawaban }}{\text { Skor kriteria tertinggi }} \times 100 \%
$$

Hasil perhitungan dikonversi pada tabel kategori interval untuk menипјиккап pusisi hasil pada garis respon (Purwiyanto, 2014) berikut:

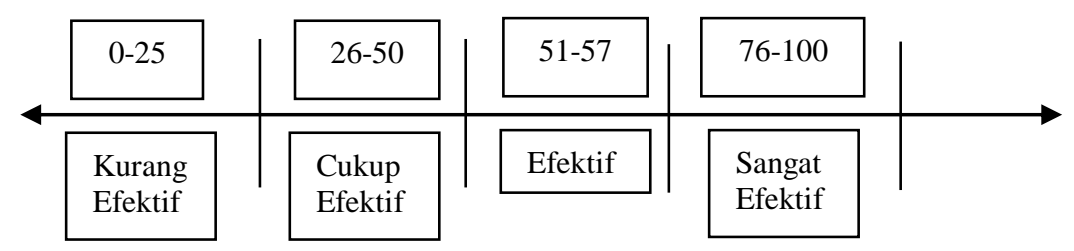

Berdasarkan hasil prosentase membandingkan akuntansi keuangam antara sesudah dengan sebelum adanya pedoman (SOP) dengan teknik before-after dengan pola $\mathrm{O}_{1}><$ $\mathrm{O}_{2}$. $\mathrm{O}_{1}$ adalah skor angket tingkat akuntansi keuagan sebelum adanya pedoman (SOP). $\mathrm{O}_{2}$ adalah skor angket tingkat akuntansi keuangan setelah adanya pedoman (SOP). Efektivitas model sistem mutu akuntansi keuangan diukur dengan membandingkan skor $\mathrm{O}_{1}$ dengan $\mathrm{O}_{2}$. Jika skor $\mathrm{O}_{2}$ lebih besar daripada $\mathrm{O}_{1}$, maka model dikatakan efektif. 
Defia Nurbatin dan Hendy Hermawan, Penelitian dan Pengembangan Sistem Mutu Akuntansi Keuangan Pada Usaha Ternak Ayam Potong Blitar .

\section{HASIL DAN PEMBAHASAN}

\section{Paparan Data Objek Penelitian}

Objek penelitian ini adalah usaha ternak ayam potong "Cak Wanto" yang dijalankan oleh Siswanto sebagai pemilik semenjak tahun 2000. Usaha peternakan ayam potong yang dirintis Siswanto merupakan ayam ras pedaging (ayam broiler). Awal mula dari hobi berternak yaitu membeli bibit ayam broiler sebanyak 20 ekor di toko peternakan. Seiring waktu hingga meningkatnya permintaan pasar, di tahun 2004 peternak Siswanto harus membangun kandang rumah ayam broiler yang lebih luas untuk memelihara ayam ternak hingga 3000 ekor. Rumah kandang ayam broiler ini berukuran panjang 65 meter, lebar 9,5 meter sehingga total luasnya adalah $2 \times(65+9,5)=149$ meter yang terletak di Desa Pohgajih Kecamatan Selorejo Kabupaten Blitar. Rumah kandang di lahan tanah yang cukup luas tersebut berdekatan dengan rumah pribadi peternak Siswanto. Oleh karenanya, setiap hari peternak Siswanto dapat mengontrol pertumbuhan ayam broiler, memberi makanan 3x dalam sehari, menyediakan air minum, menyediakan vitamin untuk menjaga kekebalan tubuh ayam broiler dari virus penyakit dan mengupayakan kebersihan kandang ayam setiap hari.

Peternak ayam selain memelihara mulai dari bibit ayam hingga siap panen ayam pedaging, dilakukan seorang diri meski kadang dibantu para tetangga yang diupah sebagai karyawan harian bila panen ternak lebih dari target. Mulai dari pembelian bibit ayam, penyediaan sarana produksi ternak dan operasional pemeliharaan tumbuh kembang bibit ternak ayam hingga siap panen (dijual) ke supplier dilakukan sendiri oleh peternak Siswanto tanpa prosedur yang tersistematis dengan pencatatan alur transaksi yang sangat manual sehingga tidak jarang kesulitan menghitung pencapaian target keuntungan penjualan panen.

Visi usaha ternak ayam potong "Cak Wanto" yaitu menyediakan ayam pedaging berkualitas melalui pemilihan bibit unggul ayam berkualitas yang ditumbukembangkan hingga siap panen dengan daging yang berkualitas, dan menguasai pangsa pasar lokal dan daerah. Sedangkan misi nya yaitu menjadi usaha ernak ayam potong yang berkualitas dan halal serta mampu menciptakan peluang usaha ternak baru yang menguntungkan seperti pengembangan ayam petelur kampung yang saat ini dirintis bersamaan dengan ayam potong pedaging broiler. Tujuan usaha ternak ayam Cak Wanto yaitu memperoleh keuntungan atas hasil jual (panen) ternak ayam dan mendukung program pemerintah mengurangi 
Defia Nurbatin dan Hendy Hermawan, Penelitian dan Pengembangan Sistem Mutu Akuntansi Keuangan Pada Usaha Ternak Ayam Potong Blitar . penggangguran dengan cara merekrut pegawai dari lingkungan sekitar peternakan sehingga terjadi pergerakan ekonomi pedesaan.

Sebagai upaya pencapaian target laba dengan meminimumkan beban operasional pemeliharaan ternak, usaha ternak "Cak Wanto" ini menggunakan pola kerjasama kemitraan yaitu peternak plasma dengan perusahaan inti. Peternak plasma dalam hal ini adalah Siswanto yang bertugas memelihara ternak bibit ayam hingga siap panen, sedangkan PT. Sinar Sarana Sentosa sebagai supplier panen ternak yang berperan selain sebagai penyedia Sarana Produksi Ternak (Sapronak) kepada peternak Siswanto, juga menjual hasil panen ternak ke pedagangpedagang besar di kota misal ke beberapa franchise bisnis restauran.

\section{Analisis Data}

Berdasarkan hasil wawancara dan observasi peneliti dengan pemilik/peternak, diperoleh informasi bahwa tidak ada pedoman standar tertulis kelola usaha ternak mulai pemeliharaan dan tumbuh kembang bibit ayam ternak (Day Old Chicken) hingga saat panen ternak sebagai ayam pedaging yang memiliki standar kualitas jual di pasar. Tidak ada sistem akutansi keuangan sebagai informasi pembukuan melalui alur transaksi kas masuk dan kas keluar saat jual beli. Misalnnya seperti pencatatan beban operasional yang dikeluarkan ke penyedia sarana produksi ternak (kandang dan kebutuhan pakan obat ternak) saat pemeliharaan serta pencatatan pendapatan per hasil panen yang diperoleh saat penjualan.

Berdasarkan hasil penelitian dan pengembangan model sistem mutu akuntansi pada peternakan ayam "Cak Wanto" di Blitar dengan pola kemitraan yang diperoleh melalui proses observasi langsung di lapangan dan wawancara, maka dihasilkan suatu Sistem Mutu berbentuk Standar Operasional Prosedur (SOP). Berikut ini adalah hasil Validasi pada tiga SOP yaitu SOP Perjanjian Jual-Beli Model Kemitraan antara Perusahaan Inti dan Plasma Peternak, SOP Akuntansi dan SOP Bagi Hasil Usaha Model Kemitraan Peternakan Ayam Potong sebagai kelola keuangan. 
Defia Nurbatin dan Hendy Hermawan, Penelitian dan Pengembangan Sistem Mutu Akuntansi Keuangan Pada Usaha Ternak Ayam Potong Blitar .

Tabel 2. Hasil Analisis SOP Perjanjian Jual-Beli Model Kemitraan Perusahaan Inti dan Plasma

\begin{tabular}{|c|c|c|c|}
\hline & Aspek Yang Dinilai & $\begin{array}{l}\text { Skor Sebelum ada } \\
\text { SOP }\end{array}$ & Skor Setelah ada SOP \\
\hline 1 & Mudah dimengerti & 2 & 5 \\
\hline 2 & Mudah Dilaksanakan & 2 & 4 \\
\hline 3 & Kelengkapan & 1 & 5 \\
\hline 4 & $\begin{array}{l}\text { Mudah diubah sesuai } \\
\text { kebutuhan }\end{array}$ & 2 & 4 \\
\hline & $\begin{array}{l}\text { Total } \\
\text { Prosentase } \\
\text { Hasil }\end{array}$ & $\begin{array}{c}7 \\
(7 / 20) * 100 \%=46 \% \\
\text { Cukup Efektif }\end{array}$ & $\begin{array}{c}18 \\
(18 / 20) * 100 \%=90 \% \\
\text { Sangat Efektif }\end{array}$ \\
\hline
\end{tabular}

Sumber : Data Validasi Ahli Praktisi (2016)

Berdasarkan Tabel 3 hitungan nilai prosentase dari setelah ada uji coba pemakaian SOP Perjanjian Jual-Beli Kemitraan antara Perusahaan Inti dan Plasma Peternak memiliki prosentase sebesar $90 \%$ atau dengan kata lain mendekati sempurna (100\%), yang artinya sesuai dengan kategori interval bahwa penerapan SOP Perjanjian Jual-Beli Kemitraan antara Perusahaan Inti dan Plasma Peternak dapat dinyatakan sangat efektif dalam hal pelaksanaan di Usaha ternak Ayam Potong "Cak Wanto". Hal ini sangat berbeda dengan sebelum ada SOP Perjanjian Jual-Beli Kemitraan antara Perusahaan Inti dan Plasma Peternak yang memiliki prosentase hanya $46 \%$.

Tabel 3. Hasil Analisis SOP Akuntansi

\begin{tabular}{|c|c|c|c|}
\hline & Aspek Yang Dinilai & Skor Sebelum ada SOP & Skor Setelah ada SOP \\
\hline 1 & Mudah dimengerti & 1 & 5 \\
\hline 2 & Mudah Dilaksanakan & 1 & 5 \\
\hline 3 & Kelengkapan & 2 & 5 \\
\hline 4 & $\begin{array}{l}\text { Mudah diubah sesuai } \\
\text { kebutuhan }\end{array}$ & 2 & 4 \\
\hline & $\begin{array}{c}\text { Total } \\
\text { Prosentase } \\
\text { Hasil }\end{array}$ & $\begin{array}{c}6 \\
(6 / 20) * 100 \%=30 \% \\
\text { Cukup Efektif }\end{array}$ & $\begin{array}{c}19 \\
(19 / 20) * 100 \%=95 \% \\
\text { Sangat Efektif }\end{array}$ \\
\hline
\end{tabular}

Sumber : Data Validasi Ahli Praktisi (2016)

Berdasarkan Tabel 4 hitungan nilai prosentase dari setelah ada uji coba pemakaian SOP Sistem Mutu Akuntansi Keuangan memiliki prosentase sebesar 95\% atau dengan kata lain mendekati sempurna (100\%), yang artinya sesuai dengan kategori interval bahwa penerapan SOP Akuntansi dapat dinyatakan sangat efektif dalam hal pelaksanaan di Usaha 
Defia Nurbatin dan Hendy Hermawan, Penelitian dan Pengembangan Sistem Mutu Akuntansi Keuangan Pada Usaha Ternak Ayam Potong Blitar . ternak Ayam Potong "Cak Wanto". Hal ini sangat berbeda dengan sebelum ada SOP Akuntansi yang memiliki prosentase hanya $30 \%$.

Tabel 4. Hasil Analisis SOP Bagi Hasil Usaha Model Kemitraan Peternakan Ayam

Potong

\begin{tabular}{|c|c|c|c|}
\hline & Aspek Yang Dinilai & Skor Sebelum ada SOP & Skor Setelah ada SOP \\
\hline 1 & Mudah dimengerti & 2 & 4 \\
\hline 2 & Mudah Dilaksanakan & 2 & 4 \\
\hline 3 & Kelengkapan & 2 & 4 \\
\hline 4 & $\begin{array}{l}\text { Mudah diubah sesuai } \\
\text { kebutuhan }\end{array}$ & 2 & 5 \\
\hline & Total & 8 & 17 \\
\hline & Prosentase & $(8 / 20) * 100 \%=40 \%$ & $(17 / 20) * 100 \%=85 \%$ \\
\hline & Hasil & Cukup Efektif & Sangat Efektif \\
\hline
\end{tabular}

\section{Sumber : Data Validasi Ahli Praktisi (2016)}

Berdasarkan Tabel 5 hitungan nilai prosentase dari setelah ada uji coba pemakaian SOP Model Kemitraan Agribisnis Peternakan Ayam Potong memiliki prosentase sebesar 85\% atau dengan kata lain mendekati sempurna (100\%), yang artinya sesuai dengan kategori interval bahwa penerapan SOP Model Kemitraan Peternakan Ayam Potong dapat dinyatakan sangat efektif dalam hal pelaksanaan di Usaha ternak Ayam Potong "Cak Wanto". Hal ini sangat berbeda dengan sebelum ada SOP Sistem Akuntansi keuangan yang memiliki prosentase hanya $40 \%$.

\section{KESIMPULAN DAN SARAN}

Berdasarkan hasil penelitian di atas diperoleh hasil bahwa model sistem mutu akuntansi keuangan yang telah disusun oleh peneliti terbagi menjadi tiga SOP. SOP Pertama yaitu Perjanjian Jual-Beli Model Kemitraan antara Plasma Peternak dan Perusahaan Inti, menunjukkan hasil bahwa setelah adanya penerapan dari SOP tersebut perjanjian jual beli kemitraan dapat berjalan dengan sangat efektif untuk diimplementasikan dengan bukti bahwa hasil prosentase menunjukkan hasil di atas $90 \%$ atau mendekati sempurna (100\%), jika dibandingkan dengan sebelum adanya SOP yang hanya menunjukkan hasil cukup efektif (46\%). Kedua, SOP Akuntansi yang menunjukkan hasil bahwa setelah adanya penerapan dari SOP tersebut, Akuntansi dapat berjalan dengan sangat efektif untuk diimplementasikan dengan bukti bahwa hasil prosentase menunjukkan hasil di atas 95\% atau mendekati sempurna (100\%), jika dibandingkan dengan sebelum adanya SOP yang hanya menunjukkan 
Defia Nurbatin dan Hendy Hermawan, Penelitian dan Pengembangan Sistem Mutu Akuntansi Keuangan Pada Usaha Ternak Ayam Potong Blitar . hasil cukup efektif (30\%). Ketiga, SOP Bagi Hasil Usaha Model Kemitraan Agribisnis Peternakan Ayam Potong yang menunjukkan hasil bahwa setelah adanya penerapan dari SOP tersebut, model kemitraan agribisnis peternakan ayam potong dapat berjalan dengan sangat efektif untuk diimplementasikan dengan bukti bahwa hasil prosentase menunjukkan hasil di atas $85 \%$ atau mendekati sempurna (100\%), jika dibandingkan dengan sebelum adanya SOP yang hanya menunjukkan hasil cukup efektif (40\%)

Adapun saran-saran yang perlu peneliti sampaikan yaitu produk SOP yang dihasilkan dalam penelitian dan pengembangan dapat diaplikasikan sebagai pedoman pembukuan terstandar akuntansi keuangan untuk pengembangan usaha ternak plasma selanjutnya, tentunya dengan melakukan perbaikan terus menerus terkait SOP yang yang telah dihasilkan.

Bagi peneliti selanjutnya dapat menambah atau mengembangkan SOP seperti SOP Sistem Informasi Akuntansi (Pendapatan dan Biaya Transaksi) dan SOP pemeliharaan dan produksi ternak ayam potong Pola Kemitraan. Dengan pengembangan SOP tersebut dapat saling melengkapi dan dijadikan acuan bagi bisnis sejenis.

\section{DAFTAR PUSTAKA}

Atmoko, Tjipto. 2012. Standar Operasional Prosedur (SOP) dan Akuntabilitas Kinerja Instansi Pemerintah. Jakarta

Borg, W. R. and Gall, M. D. 1983. Educational Research An Introduction. New York: Longman.

Ekotama, Suryono. 2010. Cara Gampang Bikin Standard Operating Procedure. Jakarta: Media Pressindo.

Hannafin, Micahel, J. and Peck, Kyle L. 1988. The Design, Development, and Evaluation of Instructional Software. New York: Macmillan Publishing Company

Insani, Istyadi. 2010. Standar Operasional Prosedur. Jakarta: Salemba Empat

Mulyadi. 2016. Sistem Akuntansi. Cetakan ke-4 Edisi Ketiga. Penerbit Salemba Empat: Jakarta.

Mulyatiningsih, Endang. 2011. Metode penelitian Terapan Bidang Pendidikan. Yogyakarta: Alfabeta.

Martani, Dwi dkk. 2012. Akuntansi Keuangan Menengah Berbasis PSAK. Buku 1. Jakarta: Salemba Empat

Nurbatin, Defia. 2016. Sebuah Model Penelitian dan Pengembangan Sistem untuk Pengelolaan Keuangan dan Pelayanan Pada Bisnis Internet. Jurnal Riset dan Aplikasi Akuntansi dan Manajemen (JRAAM) Polinema. Vol 1, No 3, Maret 2016, ISSN 2443 - 3381

Purwiyanto. 2014. Pengembangan Scorpion Model Bahan Pelatihan Memantapkan Niat Berwirausaha. Disertasi. Universitas Negeri Malang.

Purwiyanto. 2015. Pengantar Akuntansi. Malang: Surya Pena Gemilang

Robbins, Stephen P. dan Coulter, Mary. 2010. Manajemen. Edisi ke 10. Jakarta: Erlangga

Rudianto. 2012. Pengantar Akuntansi Adaptasi IFRS. Jakarta: Erlangga

Sudarwati, Ninik. 2012. Pengembangan Modul Pelatihan Kewirausahaan Pada Lembaga Kursus Keterampilan Jasa, Disertasi. Universitas Negeri Malang. 
Defia Nurbatin dan Hendy Hermawan, Penelitian dan Pengembangan Sistem Mutu Akuntansi Keuangan Pada Usaha Ternak Ayam Potong Blitar .

Sugiono. 2011. Metoda Penelitian Kuantitatif, Kualitatif, dan $R \& D$. Penerbit Alfabeta: Bandung

Setyosari, Punaji. 2010. Metode Penelitian Pendidikan dan Pengembangnnya. Jakarta: Kencana

Simatupang, P., S. Nizwar, dan U. Hadi. 2004. Arah dan Kebijakan Pengembangan Agribisnis

Peternakan di Indonesia. Seminar Nasional Komunikasi Hasil Penelitian Ternak Dan Usaha Pengembangan Peternakan Dalam Sistem Usaha Tani Lahan Kering. BPTP Nusa Tenggara Timur, Waingapu 23-24 Agustus 2004.

Sujadi. 2003. Metodologi Penelitian Pendidikan. Jakarta: Rineka cipta

Wibisono, Dermawan. 2006. Manajemen Kinerja, Konsep, Desain, dan Teknik. Meningkatkan Daya Saing Perusahaan. Jakarta: Erlangga. 
